\title{
Reply to the comment on "Geochemistry of buried river sediments from Ghaggar Plains, NW India: Multi-proxy records of variations in provenance, paleoclimate, and paleovegetation patterns in the Late Quaternary" by Singh et al. (2016), Palaeogeography, Palaeoclimatology, Palaeoecology 449 (2016) 85-100
}

Singh, Ajit; Paul, Debajyoti; Sinha, Rajiv; Thomsen, Kristina Jørkov; Gupta, Sanjeev

Published in:

Palaeogeography, Palaeoclimatology, Palaeoecology - An International Journal for the Geo-Sciences

Link to article, DOI:

10.1016/j.palaeo.2016.05.011

Publication date:

2016

Document Version

Peer reviewed version

Link back to DTU Orbit

Citation (APA):

Singh, A., Paul, D., Sinha, R., Thomsen, K. J., \& Gupta, S. (2016). Reply to the comment on "Geochemistry of buried river sediments from Ghaggar Plains, NW India: Multi-proxy records of variations in provenance, paleoclimate, and paleovegetation patterns in the Late Quaternary" by Singh et al. (2016), Palaeogeography, Palaeoclimatology, Palaeoecology 449 (2016) 85-100. Palaeogeography, Palaeoclimatology, Palaeoecology An International Journal for the Geo-Sciences, 455, 68-70. https://doi.org/10.1016/j.palaeo.2016.05.011

\section{General rights}

Copyright and moral rights for the publications made accessible in the public portal are retained by the authors and/or other copyright owners and it is a condition of accessing publications that users recognise and abide by the legal requirements associated with these rights.

- Users may download and print one copy of any publication from the public portal for the purpose of private study or research.

- You may not further distribute the material or use it for any profit-making activity or commercial gain

- You may freely distribute the URL identifying the publication in the public portal 


\section{Accepted Manuscript}

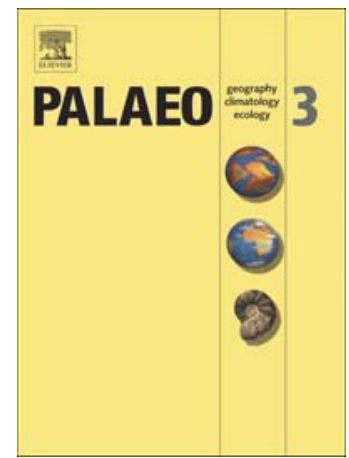

Ajit Singh, Debajyoti Paul, Rajiv Sinha, Kristina J. Thomsen, Sanjeev Gupta

PII: S0031-0182(16)30150-X

DOI: doi: 10.1016/j.palaeo.2016.05.011

Reference: PALAEO 7825

To appear in: $\quad$ Palaeogeography, Palaeoclimatology, Palaeoecology

Received date: 2 May 2016

Accepted date: 10 May 2016

Please cite this article as: Singh, Ajit, Paul, Debajyoti, Sinha, Rajiv, Thomsen, Kristina J., Gupta, Sanjeev, Reply to the comment on "Geochemistry of buried river sediments from Ghaggar Plains, NW India: Multi-proxy records of variations in provenance, paleoclimate, and paleovegetation patterns in the Late Quaternary" by Singh et al. (2016), Palaeogeography, Palaeoclimatology, Palaeoecology 449 (2016) 85-100, Palaeogeography, Palaeoclimatology, Palaeoecology (2016), doi: 10.1016/j.palaeo.2016.05.011

This is a PDF file of an unedited manuscript that has been accepted for publication. As a service to our customers we are providing this early version of the manuscript. The manuscript will undergo copyediting, typesetting, and review of the resulting proof before it is published in its final form. Please note that during the production process errors may be discovered which could affect the content, and all legal disclaimers that apply to the journal pertain. 
Reply to the comment on "Geochemistry of buried river sediments from Ghaggar Plains, NW India: Multi-proxy records of variations in provenance, paleoclimate, and paleovegetation patterns in the Late Quaternary" by Singh et al. (2016), Palaeogeography, Palaeoclimatology, Palaeoecology 449 (2016) 85-100

\author{
Ajit Singh ${ }^{\text {a,c }}$, Debajyoti Paul ${ }^{\mathrm{a}, *}$, Rajiv Sinha ${ }^{\mathrm{a}}$, Kristina J. Thomsen ${ }^{\mathrm{b}}$, Sanjeev Gupta ${ }^{\mathrm{c}}$ \\ ${ }^{a}$ Department of Earth Sciences, Indian Institute of Technology Kanpur, India \\ ${ }^{\mathrm{b}}$ Centre for Nuclear Technologies, Technical University of Denmark, Roskilde, Denmark \\ ${ }^{\mathrm{c}}$ Imperial College London, London, United Kingdom
}

\begin{abstract}
In the comment on our paper (this issue), Clift et al. (2016) compared our recently reported radiogenic $\mathrm{Nd}$-isotopic record in two drill cores (Singh et al., 2016) with those from the Hakra floodplain sediments and Indus Delta sediments. While they agree with the concept of erosion patterns in the western Himalayan sources being climatically modulated, they offer an alternative interpretation for our reported variability in the radiogenic Nd-isotopic values. Here, we show that the Nd-isotopic values for the Holocene succession instead can be explained by the bedrock geology of the source region of these sediments. Moreover, we note that whereas our paper considers a $\sim 75$ ka fluvial depositional record, their comment is only based on the post-Last Glacial Maximum (LGM) record. When considering the longer record, their arguments do not negate the main conclusions of our original paper.
\end{abstract}

Keywords: Provenance; Paleoclimate; Isotopic composition; Buried sediment; Ghaggar river 
We thank Clift et al. (2016) for initiating a discussion on understanding the coupling of climate and erosion in the western Himalaya as derived from sedimentary records. This arises from our recent publication on this topic (Singh et al., 2016). Clift et al. (2016) have compared our recently reported radiogenic Nd-isotopic record (temporal $\varepsilon_{\mathrm{Nd}}$ variability, see Fig. 10 in Singh et al., 2016) in two drill cores (GS-10 and GS-11) from alluvial sediments in the Ghaggar Plains of NW India, with those from the Hakra floodplain sediments in the greater Ghaggar region (Alizai et al., 2011; East et al., 2015) and Indus Delta sediments (Clift et al., 2008). This comparison is shown in Fig. 1 of Clift et al. (2016). Whilst Clift et al. (2016) agree with the concept of climate-modulated erosion in the Himalayan sources of these fluvial sediments, they offer an alternative explanation for our reported radiogenic Nd- isotopic record. We note that their comment only focuses on the post-Last Glacial Maximum (LGM) record whereas our paper documents the depositional record for the past $\sim 75 \mathrm{ka}$. Below we discuss the specific details of their comment and examine the broader implications of our data.

Before continuing the discussion, we correct one data point shown in Fig. 1 of Clift et al. (2016). This data point from the Indus Delta sediment record is plotted at $\sim 15 \mathrm{ka}$ and shows a $\varepsilon_{\mathrm{Nd}}=$ -10.8 in Clift et al. (2016). However, the same sample is identified as KB-40-5 (see Supplementary Table DR2, Clift et al., 2008) with a date of $28.7 \mathrm{ka}$. Presuming the published record to be correct, we have plotted this data point in our Fig. 1 taking into account the correct age for that sample. We have also performed Kernel Density Estimates (KDE) of $\varepsilon_{\mathrm{Nd}}$ values for the modern day Sutlej, Yamuna, and Ghaggar river sediments, and the Thar Desert sediments (Tripathi et al., 2013 and Alizai et al., 2011). This shows that the variation of $\varepsilon_{\mathrm{Nd}}$ values in the GS-10 core falls within the range of the modern Ghaggar river (Fig. 1) though there is an overlap in the KDE plots of data from the modern Ghaggar and the Thar Desert (1.8 to $9.1 \mathrm{ka}$ ) sediments. We do not agree with the argument of Clift et al. (2016) that the $\varepsilon_{\mathrm{Nd}}$ temporal evolution in the Ghaggar and Indus basins should show a similar trend because they are adjacent to each other. Rather, we posit that isotopic values of (fluvial) sediment mixtures are most likely related to the relative contributions of end-member sources, which in turn is strongly dependent on the catchment lithology. While the Indus basin includes the Karakoram $\left(\varepsilon_{\mathrm{Nd}}\right.$ : 
-12 to -8$)$ and Trans-Himalayan ( $\varepsilon_{\mathrm{Nd}}:-1$ to +8 ; see Fig. DR2 in Clift et al., 2008) sources along with the Higher and Lesser Himalaya (HH and LH) sources, the Sutlej catchment predominantly drains the $\mathrm{HH}$ and LH sources, and the Ghaggar river drains the Sub-Himalaya. This is reflected in the more positive $\varepsilon_{\mathrm{Nd}}$ values for the Indus Delta sediments compared to those of the Ghaggar sediments.

In our paper (Singh et al., 2016), we documented the $\varepsilon_{\mathrm{Nd}}$ variability in dated sediment cores through alluvial strata spanning a time interval from $\sim 75$ ka to the Holocene. We presented a $\varepsilon_{\mathrm{Nd}}$ record that shows temporal variability that can potentially be linked to Late Quaternary climatecontrolled erosion in the Himalayan source areas supplying these sediments. Clift et al. (2016) focus on the post-LGM record. Our data show that the $\varepsilon_{\mathrm{Nd}}$ of Ghaggar sediments increases by $\sim 2 \varepsilon$ units from MIS2 (>14 ka) to MIS1. This is in contradiction to the observations by Clift et al. (2008) from the Indus Delta sediments where they document a decreasing $\varepsilon_{\mathrm{Nd}}$ trend of similar magnitude during the same time period. Clift et al. (2016) propose that the shift in $\varepsilon_{\mathrm{Nd}}$ we observe in our cores from MIS2 to MIS1 does not require a climate-controlled change in the Himalayan source areas but can be explained by admixture of more radiogenic aeolian sediments from the Thar Desert. Whilst this is a plausible hypothesis, we offer here a better explanation for this $\varepsilon_{\mathrm{Nd}}$ variability. In our paper, we did not explicitly discuss the causes of the $\varepsilon_{\mathrm{Nd}}$ variability for the post-LGM transition. The sediments in our core GS-10, deposited during MIS1, are very fine-grained sands and silts with a distinctive reddish-brown colour. We interpret these as deposits of the Ghaggar river that has its headwaters in the Sub-Himalaya (Singh, 2014). The older sediments in the GS-10 and GS-11 cores are coarsegrained fluvial sands that are likely deposits of a Himalayan sourced river (Sinha et al., 2013). We have inferred that this transition may record a major river shift (Sinha et al., 2013; Singh et al., 2015; Singh et al. manuscript in prep.). The Ghaggar river sediments are derived from erosion of early Himalayan foreland basin sedimentary rocks that are now exposed in the headwaters of the modern Ghaggar river. These include foreland basin strata of the Dagshai and Kasauli Formations that were derived from erosion of dominantly Higher Himalayan crystalline rocks during the OligoceneMiocene (Najman et al., 2000; Ravikant et al., 2011). The $\varepsilon_{\mathrm{Nd}}$ of modern Ghaggar and GS-10 core sediments show similar range as that of the Higher Himalaya as seen in the bivariate plot of $\mathrm{Sr}$ and $\mathrm{Nd}$ 
isotopic ratios (Fig. 6 of Singh et al., 2016). Thus the $\varepsilon_{\mathrm{Nd}}$ transition from MIS2 to MIS1 in our cores is best explained neither by a climatically controlled shift in Himalayan erosional source region, nor by admixture of aeolian sediments from the Thar desert, but by a transition from deposition by a Himalayan-sourced river to deposition by the foothills-sourced Ghaggar river (Sinha et al., 2013; Singh et al., 2015; Singh et al., manuscript under prep.). Because the Hakra floodplain sites documented by Clift et al. (2016) are downstream of the Ghaggar floodplain and likely connected, the $\varepsilon_{\mathrm{Nd}}$ records for the Holocene Hakra floodplain sediments are also best explained as the deposits of the Ghaggar river- with more positive $\varepsilon_{\mathrm{Nd}}$ because of their derivation from Sub-Himalayan foreland basin rocks.

However, our older sediment records (e.g., GS-11 core) do show $\varepsilon_{\mathrm{Nd}}$ variability within the range reported for the HH and LH units in NW Himalaya (Fig. 6 of Singh et al., 2016). The temporal variation in $\varepsilon_{\mathrm{Nd}}$ shows an increase from less radiogenic $\left(\varepsilon_{\mathrm{Nd}}=-19.0\right)$ during MIS4 to more radiogenic $\left(\varepsilon_{\mathrm{Nd}}=-17.0\right)$ during MIS3. We explain this temporal variability as the result of variable contribution from the LH and $\mathrm{HH}$ endmembers in the NW Himalayan source region. In our paper (Singh et al., 2016), we concluded that an increase in sediment contribution from LH (less radiogenic Nd-isotopic ratios) during MIS4 glacial period followed by an increase in sediment contribution from $\mathrm{HH}$ (more radiogenic) during MIS3 interglacial can explain the variation of $\varepsilon_{\mathrm{Nd}}$ in the GS cores. As there is no record available from the Indus Delta for this time period, we cannot compare older isotopic records of GS cores with that of available data on Indus Delta sediments.

Sediment production and evacuation in the NW Himalaya in response to climate change is a topic of much recent debate. We agree with Clift et al. (2016) that interpretation of geochemical records to reconstruct the distribution of erosion in Himalayan catchments requires a thorough understanding of geomorphologic and sedimentary contexts. Moreover, better knowledge of erosional processes in source regions and delivery of sediment from glaciated catchments is also required before establishing a unique model of climate-erosion coupling that also explains the spatial distribution of erosional patterns in Himalayan sources. 


\section{References}

Alizai, A., Clift, P.D., Giosan, L., Vanlaningham, S., Hinton, R., Tabrez, A.R., Danish, M., EIMF, 2011. $\mathrm{Pb}$ isotopic variability in the modern and Holocene Indus River system measured by ion microprobe in detrital K-feldspar grains. Geochim. Cosmochim. Acta 75, 4771-4795.

Clift, P.D., Giosan, L., East, A.E., 2016. Comment on "Geochemistry of buried river sediments from Ghaggar Plains, NW India: Multi - proxy records of variations in provenance, paleoclimate, and paleovegetation patterns in the late quaternary" by Ajit Singh, Debajyoti Paul, Rajiv Sinha, Kristina J. Thomsen, Sanjeev Gupta. Palaeogeogr. Palaeoclimatol. Palaeoecol., this issue.

Clift, P.D., Giosan, L., Blusztajn, J., Campbell, I.H., Allen, C.M., Pringle, M., Tabrez, A., Danish, M., Rabbani, M.M., Carter, A., Lückge, A., 2008. Holocene erosion of the Lesser Himalaya triggered by intensified summer monsoon. Geology 36 (1), 79-82. doi: 10.1130/G24315A.1.

East, A.E., Clift, P.D., Carter, A., Alizai, A., VanLaningham, S., 2015. Fluvial-eolian interactions in sediment routing and sedimentary signal buffering: an example from the Indus basin and Thar Desert. J. Sediment. Res. 85, 715-728. doi:10.2110/jsr.2015.42.

Najman, Y., Bickle, M., Chapman, H., 2000. Early Himalayan exhumation: Isotopic constraints from the Indian foreland basin. Terra Nova 12, 28-34.

Ravikant, V., Wu, F.-Y., and Ji, W.-Q., 2011. U-Pb age and Hf isotopic constraints of detrital zircons from the Himalayan foreland Subathu sub-basin on the Tertiary palaeogeography of the Himalaya. Earth Planet. Sci. Lett. 304 (3-4), 356-368.

Singh, A., 2014. Subsurface stratigraphy, sediment geochemistry, and paleoclimatic reconstruction in Ghaggar plains in NW India: linkage of landscape evolution and cultural heritage. Ph.D. thesis, Indian Institute of Technology Kanpur, India.

Singh, A., Gupta, S., Sinha, R., Carter, A., Kristina, K.J., Mark, D.F., Buylaert, J-P., Mason, P.J., Murray, A.S., Jain, M., Paul, D., 2015. Large-scale avulsion of the late Quaternary Sutlej river in the NW Indo-Gangetic foreland basin, Geophys. Res. Abstr. 17, EGU General Assembly Conference, Abstracts EGU2015-6661.

Singh, A., Paul, D., Sinha, R., Thomsen, K.J., Gupta, S., 2016. Geochemistry of buried river sediments from Ghaggar Plains, NW India: Multi - proxy records of variations in provenance, paleoclimate, and paleovegetation patterns in the Late Quaternary. Palaeogeogr. Palaeoclimatol. Palaeoecol. 449, 85-100. doi: 10.1016/j.palaeo.2016.02.012.

Sinha, R., Yadav, G.S., Gupta, S., Singh, A., Lahiri, S.K., 2013. Geo-electric resistivity evidence for subsurface palaeochannel systems adjacent to Harappan sites in northwest India. Quat. Int. 308309, 66-75.

Tripathi J.K., Bock B., Rajamani V., 2013. Nd and Sr isotope characteristics of Quaternary IndoGangetic plain sediments: Source distinctiveness in different geographic regions and its geological significance. Chem. Geol. 344, 12-22. doi: 10.1016/j.chemgeo.2013.02.016. 


\section{Figure Caption}

Figure 1. Kernel density estimation (KDE) plot of $\varepsilon_{\mathrm{Nd}}$ values in the modern Sutlej, Ghaggar and Yamuna, and Thar Desert sand (Tripathi et al., 2013 and Alizai et al., 2011). Also shown are temporal variabilities in $\varepsilon_{\mathrm{Nd}}$ of Indus Delta sediments (Clift et al., 2008) and drill core sediments from Ghaggar (Singh et al., 2016) and Hakra floodplains (Alizai et al., 2011 and East et al., 2015). 


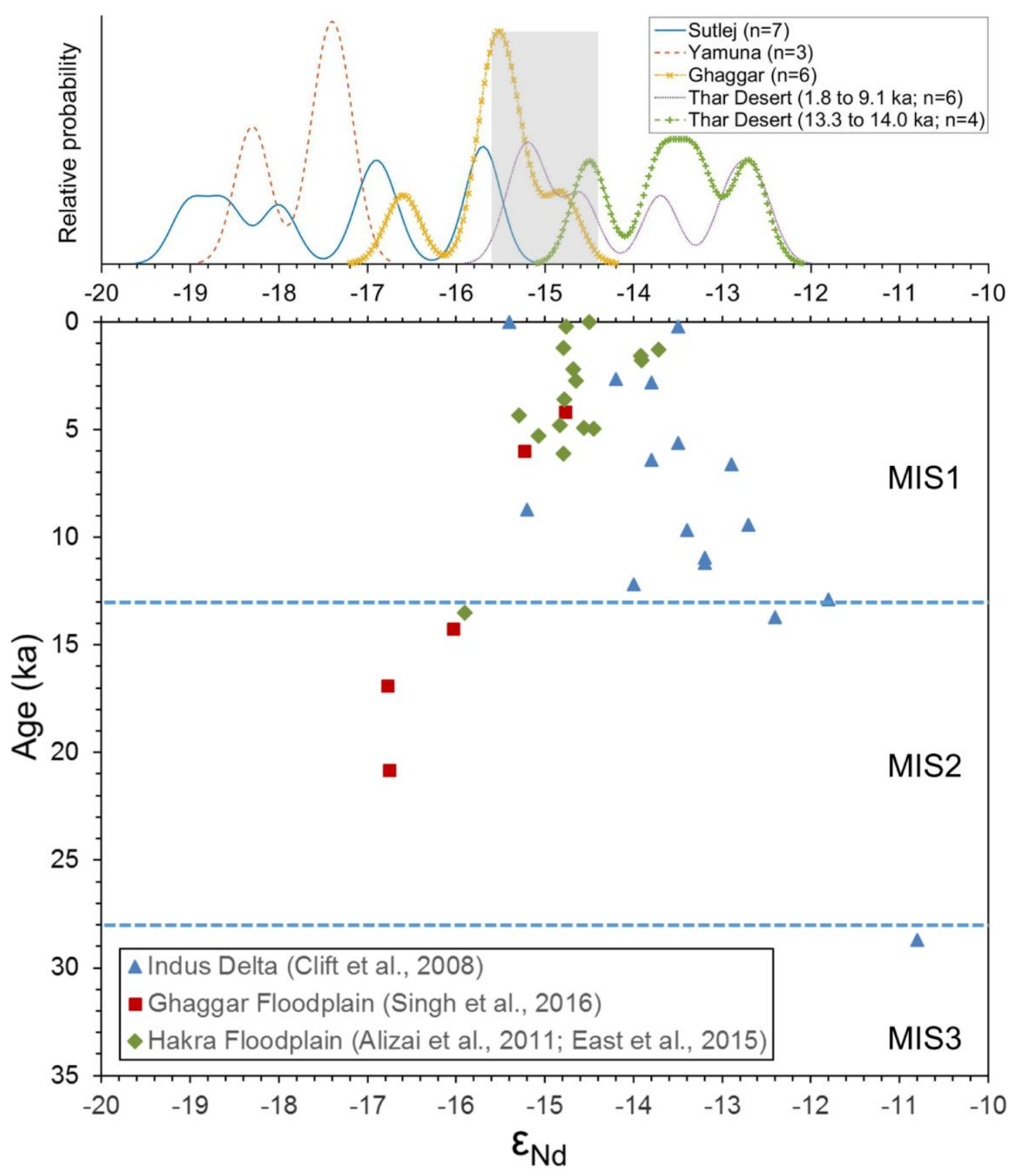

Figure 1 